\title{
Entrepreneuring after 50: the liminal identity transitions of older emergent entrepreneurs
}

\author{
Lucia Garcia-Lorenzo \\ London School of Economics and Political Science, L.Garcia@lse.ac.uk \\ Lucia Sell-Trujillo \\ Universidad de Sevilla \\ Paul Donnelly \\ Technological University Dublin, paul.donnelly@tudublin.ie
}

Follow this and additional works at: https://arrow.tudublin.ie/buschmarart

Part of the Business Administration, Management, and Operations Commons, and the Entrepreneurial and Small Business Operations Commons

\section{Recommended Citation}

Lucia Garcia-Lorenzo, Lucia Sell-Trujillo \& Paul Donnelly (2020) Entrepreneuring after 50: the liminal identity transitions of older emergent entrepreneurs, Entrepreneurship \& Regional Development, 32:9-10, 922-942, DOI:10.1080/08985626.2020.1849408

This Article is brought to you for free and open access by the School of Marketing at ARROW@TU Dublin. It has been accepted for inclusion in Articles by an authorized administrator of ARROW@TU Dublin. For more information, please contact arrow.admin@tudublin.ie, aisling.coyne@tudublin.ie,gerard.connolly@tudublin.ie.

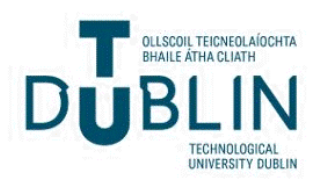




\section{Entrepreneurship \& Regional Development}

\section{Entrepreneuring after 50: the liminal identity transitions of older emergent entrepreneurs}

\section{Lucia Garcia-Lorenzo, Lucia Sell-Trujillo \& Paul Donnelly}

To cite this article: Lucia Garcia-Lorenzo, Lucia Sell-Trujillo \& Paul Donnelly (2020) Entrepreneuring after 50: the liminal identity transitions of older emergent entrepreneurs, Entrepreneurship \& Regional Development, 32:9-10, 922-942, DOI: 10.1080/08985626.2020.1849408

To link to this article: https://doi.org/10.1080/08985626.2020.1849408

曲 Published online: 24 Nov 2020.

Submit your article to this journal

Џll Article views: 288

Q View related articles $₫$

View Crossmark data $\asymp$

Citing articles: 2 View citing articles 


\title{
Entrepreneuring after 50: the liminal identity transitions of older emergent entrepreneurs
}

\author{
Lucia Garcia-Lorenzo ${ }^{a}$, Lucia Sell-Trujillo ${ }^{b}$ and Paul Donnellyc \\ aPsychological and Behavioural Science, London School of Economics and Political Science, London, United \\ Kingdom of Great Britain and Northern Ireland; 'bocial Psychology, Universidad De Sevilla, Sevilla, Spain; 'College \\ of Business, Technological University Dublin, Dublin, Ireland
}

\begin{abstract}
Entrepreneurship has been proposed as a solution to extending working lives. However, little is known about how older (50+) entrepreneurs manage their personal transitions into entrepreneurship. In this paper, we propose to use a liminal identity work perspective to explore the identity paradoxes that older entrepreneurs experience during their transition into entrepreneurship and how they manage it. We use a qualitative study conducted over 14 months in the United Kingdom. Our analysis shows how older entrepreneurs confront identity paradoxes, interruptions and identity polarization in their attempts to shift from older identities and activity patterns into new ones. The entrepreneurs who manage to overcome the identity interruptions and polarization that the transition brings move away from an initial sense of isolation and bring creative understandings to older entrepreneuring processes. Our results expand current understanding of entrepreneurial identity work in liminal conditions, especially among older entrepreneurs, by looking at the tensions emerging between potentially new and customary identities and behaviours as an important aspect of entrepreneuring transitions rather than as negative frictions to be avoided.
\end{abstract}

\section{ARTICLE HISTORY}

Received 23 May 2019

Accepted 23 October 2020

\section{KEYWORDS}

Older entrepreneurs; liminality; employment transitions; identity work; narratives

\section{Introduction}

Entrepreneurship is being proposed as a solution to extending working lives in the context of an increasingly ageing population (World Economic Forum 2018). Older (50+) people also face challenges of late life (un)employment, retirement and pension shortfalls due to recent changes in employer-sponsored pension schemes and the declining value of personal savings (Kibler et al. 2015). While older entrepreneurship is seen as a potential silver lining to an older, non-taxcontributing population (Stirzaker and Galloway 2017), older workers are still discriminated against in society and the labour market (Riach and Loretto 2009). Thus, older entrepreneurs find themselves in the paradoxical situation of being encouraged to take on the risks associated with starting up a business while still suffering social exclusion in a context of increasing economic uncertainty (Kibler et al. 2015). Despite older entrepreneurship receiving increasing scrutiny (Kautonen, Tornikoski, and Kibler et al. 2011), relatively little is known about the entrepreneurial potential of older individuals (Hart et al. 2004), particularly about how older entrepreneurs manage their personal identity transitions into entrepreneurship. We address this gap by exploring the transition into entrepreneurship among older entrepreneurs from a liminal and narrative identity work perspective.

CONTACT Lucia Garcia-Lorenzo L.Garcia@lse.ac.uk E Psychological and Behavioural Science, London School of Economics and Political Science, London WC2A 2AE, United Kingdom of Great Britain and Northern Ireland 
Our paper contributes to the emergent research tradition that frames entrepreneurship as a temporary and evolving process (Steyaert 2007), and entrepreneurial identities as developed through the on-going engagement of entrepreneurs with their context (Mallett and Wapshott 2015) and enacted in identity narratives (Hamilton 2014). We also respond to recent calls for more process based identity research (Leitch and Harrison 2016), more focus on the dynamic processes in older entrepreneurial ventures at their early stages (Hytti et al. 2018), and more qualitative empirical research on the social and cultural perceptions of old age entrepreneurship (Kautonen 2008a). We expand this research by framing entrepreneurial identity development as a liminal and transformative condition, a process of creating possible futures and states of being. We understand liminality as a condition of paradoxical, in-between identities and social positions that can prompt older entrepreneurs to develop new identities, ultimately altering their current patterns of activity.

We explore older entrepreneurs' transitions into entrepreneurship through a qualitative study conducted over 14 months in the United Kingdom (U.K.). The process of millions of individuals entering into their retirement years, while being financially ill-prepared to cease work entirely, is not an exclusively U.K. phenomenon, however, as it is a vulnerability further revealed by the recession that began in 2008. We show how older entrepreneurs manage their liminal condition and the paradoxes it generates through the process of identity work, that is, through the range of activities they engage in to create, present, and sustain personal identities congruent with a self-concept (Sveningsson and Alvesson 2003). We develop previous identity work in entrepreneurship (Leitch and Harrison 2016), highlighting the importance of the positions older entrepreneurs take and assign to others when describing their transition.

Our research complements current entrepreneuring studies by looking at the tensions emerging between potentially new and customary identities and behaviours as an important aspect of entrepreneuring transitions, rather than as negative frictions to be avoided. Furthermore, by uncovering the liminality inherent in their transitions, our research captures the creative capacity of entrepreneuring as a process in which older entrepreneurs attempt to develop new entrepreneuring ventures and recreate themselves and their context anew. These results expand current understandings of entrepreneurial identity work in liminal conditions, especially among older entrepreneurs.

Our paper is structured as follows. We begin by outlining the notion of liminal identity work among older entrepreneurs underpinning our research. Then, we elaborate our methodology. Thereafter, we present our findings in the form of liminal identity work narratives, before concluding with a discussion of our findings and the contributions of our study.

\section{Becoming an older entrepreneur}

The literature defining entrepreneurial work in later life uses several terms to describe this population (Biron and St. Jean 2019). We use the term older entrepreneurs to describe adults aged 50 + engaging in new entrepreneurship practices. While this seems to be the generally accepted age range for describing later-life entrepreneurship (Biron and St. Jean 2019), we do not assume that the motivations, experiences, and outcomes of all older entrepreneurs are the same.

The understanding of the process of becoming an entrepreneur has evolved from a focus on individual traits and decision-making into something more relational and embedded (De Clercq and Voronov 2009), where entrepreneurial identity is understood as developed through entrepreneurs' on-going engagement with their context (Mallett and Wapshott 2015). Identities are pluralistic accomplishments (Down and Reveley 2004), where the 'situated character of self-identifications' (Fine 1996, 112) results from 'negotiating the meanings of our experience of membership in social communities' (Wenger 1998, 145). Invoking generational differences is one 'way of classifying the identity of self and other' (Parker 2000, 188), with Down and Reveley (2004) illustrating how a younger generation aspiring to be entrepreneurs use an oppositional strategy of comparing themselves to an older generation to reflexively construct a 'stable sense of self-identity' (Giddens $1991,54)$ as entrepreneurs. 
The emergent body of research on older entrepreneurship focuses on themes such as entrepreneurial predispositions and motives (e.g., Kautonen et al. 2008b), resources required to become an entrepreneur (e.g., Singh and DeNoble 2003), and institutional and social contexts influencing the process (e.g., Weber and Schaper 2004). The disinclination to choose entrepreneurship after a certain age is explained by the rising opportunity cost of time, which dissuades older individuals from choosing forms of employment that involve risk or delaying gratifications (Lévesque and Minniti 2006). While the willingness to start a business decreases with age, the opportunity to do so increases owing to the resources needed accumulating with age (Henley 2007). Compared to younger entrepreneurs, older individuals have the benefits of work experience, higher levels of technical and managerial competencies, more financial resources (Kautonen et al. 2008b), and more social capital (Weber and Schaper 2004). Increased financial resources can both act as incentive to entrepreneurship, as they provide financial support for start-up, while lowering the interest of wealthy individuals in becoming an entrepreneur, as they can consume retirement funds (Singh and DeNoble 2003).

Older individuals are enticed into entrepreneurship when faced with the prospect of increased earnings, the opportunity to pursue ideas independently (Weber and Schaper 2004), the fear of becoming unemployed or losing welfare benefits and income (Kautonen et al. 2008b). Although enterprise support policies aim to assist individuals considering entrepreneurship, formal institutional support, such as state benefits or retirement incomes, can discourage older entrepreneurs from actively searching for enterprise support agencies (Kautonen et al. 2008b). Social and cultural understandings also shape older individuals' firm formation processes (e.g., Kautonen, Tornikoski, and Kibler et al. 2011), with age determining entrepreneurial preferences (Parker 2009). However, despite age and older entrepreneurship receiving increased scholarly and policy attention (Kautonen, Tornikoski, and Kibler et al. 2011; Lévesque and Minniti 2011), relatively little is known about how older entrepreneurs manage their personal identity transitions into entrepreneurship.

The linguistic metaphor of identity work is useful in capturing the dynamic aspects and constant struggles of identity construction in complex and fragmented contexts, such as the liminal state older entrepreneurs find themselves in (Brown 2015). Identity work has been defined as the set of processes through which people develop narratives of the self in a context where external influences seek to impact on, or regulate, the nature of that self-meaning (Alvesson 2010). A distinct characteristic of identity work is that identities are understood as temporary, negotiated and contested in ongoing self-reflection and social interactions (Beech 2011). Further, identity work looks at how particular narratives become imbued with meaning and are taken or rejected as being part of one's identity. Thus, identity work is also a process of absorbing, personalizing and enacting general narratives or being constrained by them (Mallett and Wapshott 2015).

The narrative approach to identity work we use sees identity as held in repertoires of co-existing self-narratives that are selectively used in response to the context and purpose of particular practices and interactions (Toyoki and Brown 2014), a view we further by emphasizing the significance of the perspective and the position the author takes in each narrative (Boje and Smith 2010). Thus, when older entrepreneurs position themselves in entrepreneuring narratives, they produce a particular self (Davies and Harré 1990) infused with the voices of the generalized 'other', making the positioning of the self in the narrative a joint relational effort between self, other and context (van Langenhove and Harré 1999). The positions that older entrepreneurs take and assign to others in these narratives relate also to particular images, narratives, and practices of entrepreneurship through which they do and redo entrepreneuring (Steyaert 2007). As such, as the older entrepreneur's narrative position changes, their perception of entrepreneuring, along with the way they act, changes too. This multivoiced nature of the entrepreneurial self is an adaptive response to the fractured social world we traverse (Gioia and Thomas 1996), explaining its critical relevance in liminal contexts, such as the ones older entrepreneurs face.

Identity work seems particularly necessary in liminal conditions, where strains and tensions, which prompt feelings of confusion, contradiction and self-doubt, and lead to an examination of the self, are prevalent (Lutgen-Sandvik, 2008). We now move to outline this liminal identity process. 


\section{Confronting identity paradoxes in the liminal transition to older entrepreneuring}

In organization studies, liminality has been considered as a structurally imposed condition by virtue of a profession or a particular role (Daskalaki and Simosi 2018) and is often associated with negative consequences. In entrepreneurial terms, liminality has been used more positively to indicate transformative spaces (García-Lorenzo et al. 2018) that allow entrepreneurs to discover their true selves (Brooker and Joppe 2013), where new, possible futures, not yet formed, exist side-by-side with current trajectories (Henfridsson and Yoo 2014). Thus, entrepreneurship research has started to outline how liminal conditions can prompt emergent entrepreneurs to develop new possibilities that can ultimately alter current patterns of activity.

The term 'liminal' was first used by van Gennep (1960) to name the middle or transition phase of a three-phase rite of passage that begins with separation (end of previous identity and social position) and ends with aggregation (new identity and social position adopted). Rites of passage are enacted at culturally and socially significant points of transition, such as when moving from active employee to retired person, with each stage outlining identities and clear areas of social activities. Turner (1977a) further developed the concept, calling this in-between stage 'antistructure', to stress the opposition of the liminal to clearly articulated social structures. Thus, liminality removes limits from everyday life, so everything is open to question, with 'liminal personae' having no defined and recognized social or institutional position: they are in-between and betwixt (Turner 1977a, 95). Along with transgression, inversion, and parody, liminal processes notably include the reflexive contemplation of structures that have been suspended, which enables and inculcates a critical and creative attitude (Daskalaki and Simosi 2018). Accordingly, liminal transitions can be a dangerous time, with no sure standards for behaviour, but also a space/time where potentiality exists (Turner 1977b). Hence, liminality 'significantly disrupt[s] one's internal sense of self or place within a social system' (Noble and Walker 1997, 31) and triggers both identity and contextual reconstruction in such a way that a possible new identity and social position might be developed (Beech 2011).

An important characteristic of liminality as an interstructural space is that it is paradoxically defined by what it is not, rendering confusion and ambiguity typical (Turner 1977b). Normally incompatible elements of the conditions in between which the interstructural state is found will be paradoxically juxtaposed and recombined (Turner 1977b); elements of existence may be found severed from their usual context, juxtaposed by their usually mutually exclusive opposite, and assembled into new, potentially nonsensical combinations. Our liminal approach to entrepreneurial identity transitions aims to capture identity paradoxes characteristic of liminality to better understand how older entrepreneurs navigate the transition from employee to older entrepreneur.

Paradox in organizational life (Schad et al. 2016) has been defined as 'contradictory yet interrelated elements that exist simultaneously and persist over time' (Smith and Lewis 2011, 382) and are constituted by the tensions arising between different sides of the paradox (Lewis and Smith 2014). Even if the result is a shifting relationship between alternative poles (Smith et al. 2017), the core elements of the paradox - contradiction, interdependence, and persistence - are expected to remain, impervious to resolution (Schad et al. 2016). Traditionally, paradox is regarded as a dysfunctional state to be eliminated, often looking for resolution by choosing one of the extremes. But, by seeking to resolve paradoxes, organizations and individuals risk falling into 'simplicity traps' that might aid short-term performance (Lewis 2000, 765), removing the complications that support more innovative performances only achievable through continuous efforts to meet multiple, divergent demands (Lewis 2000).

Once rendered salient, paradoxical identity tensions stimulate responses that fuel reinforcing cycles, which can be negative or positive (Lewis 2000). Negative cycles stem from such factors as cognitive and behavioural forces for consistency, emotional anxiety and defensiveness, and institutional forces for inertia (Cialdini, Trost, and Newsom et al. 1995). Individuals may also react by choosing one identity, altering their beliefs or actions to enable a consistent response, or by 
maintaining a commitment to previous identities and behaviours to enable consistency between past and future (Cialdini, Trost, and Newsom et al. 1995). Such identity commitments become reinforced by social dynamics that embed inertia in structures, routines, and/or processes where the future becomes wedded to the past (Eisenhardt and Martin 2000). A more positive response to paradoxical tensions is where awareness of tensions triggers a strategy of development rather than defensiveness (Lüscher and Lewis 2008). Development encourages actors to embrace or live with paradox (Lewis 2000), and entails viewing identity tensions as an invitation for creativity and opportunity (Beech et al. 2004).

To sum up, liminal transitions among older entrepreneurs can be seen as a transition from one status to another (Czarniawska and Mazza 2003) or as a 'limbo of statuslessness' (Turner 1977a, 97) on a journey towards new roles and understandings. This has implications for how older entrepreneurs understand subjectivities through blurred, paradoxical or transitional identities. On this basis, liminal transitions can lead to confusion over identities, positions and routines, as individuals find themselves separated from existing structures and familiar ways of doing and being. We describe this process below.

\section{Methodology}

Identity, as Berger and Luckmann $(1966,195)$ argue, 'remains unintelligible unless it is located in a world', and our interest in liminal identity work narratives is located in the world of older entrepreneurship. Older people increasingly have to develop alternatives to tackle challenges of late life retirement or pension shortfalls through self-employment and entrepreneurship (Kibler et al. 2015). The U.K. is an example of this trend, with the country's Office for National Statistics (2019) noting some $15 \%$ of the U.K. workforce, or 4.5 million people, were self-employed as of 2019 . Of these, $43 \%$ were over 50, while the number over 65 doubled since the 2008 global financial crisis.

The U.K. government has sought to move towards a private system of pension provision, whilst larger firms are reducing future pension incomes for older people (Langley 2006; Pensions and Lifetime Savings Association 2010). Though the government is notably concerned about the financial burden (non-employed) older people represent for the state, very little support exists for them to become economically active (Kautonen, Down, and Minniti et al. 2014). While our study is based in the U.K., individuals transitioning to retirement financially ill-prepared to cease work entirely are common across the developed world, leading to an overall increase in self-employment among older people (Gerontological Society of America 2018; Hatfield 2015).

To understand the experiences of older people undergoing the transition into entrepreneurship, we have used a qualitative research design, conducting in-depth interviews, along with reading publicly available documents and public narratives of entrepreneurship in the U.K. as background to understand older entrepreneurs' personal experiences within the current socio-cultural-historical U.K. context.

\section{Data generation}

We interviewed 55 older entrepreneurs, using established entrepreneurship networks - Prince's Initiative for Mature Enterprise (PRIME) (a charitable organization supporting 50+ entrepreneurs), Key Person of Influence (a commercial entrepreneurial development programme), and Penna (a company that provides redundancy programmes for large organizations) - and personal contacts and networks to generate the interviews. The interviews were conducted in various public places, as well as in individuals' homes when no other location was available. The average interview length was 60 minutes - the longest was 2 hours and the shortest 40 minutes - and every interview was taperecorded and followed British Psychological Society ethical guidelines. During the in-depth interview process, we asked participants about their transition from different (un)employment conditions towards entrepreneurship, as well as their experiences as emergent entrepreneurs, focusing on generating personal stories and the non-completed narratives that address transitions, doubts, and unfinished processes. 
Our main criterion for interviewee selection was the length of time setting up a business. Following the Global Entrepreneurship Monitor classification (Xavier et al. 2013, 19), we sought participants who were in the process of business creation for more than three months, but less than 42 months, with our sample ranging from three months to 36 months. Interviewees comprised both recently unemployed and those working previously, and they came from a wide range of backgrounds, with different educational levels and professional working experiences. Most were living and working in the London area, with ten coming from the Midlands. We did not discriminate in terms of the business they were in, and we included those who set up on their own (sole traders) and with a partnership of some kind. We have a reasonable gender balance (31 males and 24 females), and most participants were aged between 50 and 65, with the oldest 83 .

\section{Data analysis}

All interviews were digitally recorded and transcribed verbatim for thematic and narrative analysis using NVivo, and followed inductive and deductive approaches and quality indicators to meet required qualitative research standards (Gioia, Corley, and Hamilton et al. 2013). All researchers participated in this codification process and common work was carried out to interpret the data.

The data were analysed in two stages. First, we conducted a full thematic analysis (see Figure 1) with all interviews to identify and analyse patterns of meaning across our dataset. This analysis also enabled us to obtain general knowledge about differences and similarities in the entrepreneuring process, challenges that older entrepreneurs face, older entrepreneurs' daily engagement with the entrepreneuring process, older entrepreneurs' routines and practices, and the different entrepreneuring interactions older entrepreneurs reported as experiencing. These themes, among others, were included in the coding framework as first order concepts (Gioia, Corley, and Hamilton et al. 2013). Second order themes emerged as our analysis uncovered the liminal (Turner 1977b) transition older entrepreneurs undergo: first, separating from a previous, clear professional identity and position in their social structure; second, living in an unstructured social and personal period of uncertainty; and third, in few cases, starting to outline a new identity and social position as entrepreneurs.

After obtaining an overall view of how interviewees understood the different stages of their liminal transition into entrepreneuring, we sought to identify particular identity struggles and their links to concrete entrepreneuring practices through a second analysis (see Figure 2). For this, we followed organizational identity research that theorizes identities as texts constructed through language, discourses and narratives (Harré et al. 2009). We focused on personal narratives, where older entrepreneurs described the process of entrepreneuring and positioned themselves within particular entrepreneuring events in relation to other significant actors (Riessman 2008), as well as within local and wider discourses that justified and sustained their positioning. The personal stories illustrated older entrepreneurs' ability to (re)produce and (re)create identities through identity work (McAdams and McLean 2013).

Within each personal narrative, we identified three main identity tensions, which, following both the literature on paradox (e.g. Lewis and Smith 2014), we call 'confronting paradox', 'interruption and polarization', and 'pattern shift'. The way older entrepreneurs described the uncertain and ambiguous experience of transition towards entrepreneurship is akin to encountering a paradox. In our older entrepreneurs' case, the paradox arose from attending to the requirements of mutually incompatible identities and social positions (e.g., employee and entrepreneur). They also report that living in a liminal state and encountering an identity paradox confuses and interferes with their flows of activity, generating an interruption (e.g., being an employee has certain activity requirements that get interrupted when one becomes unemployed). In trying to escape their predicament of indeterminacy, they forge a solution that conforms to discourses and social positions they are caught between, generating a polarization of discourses and activities (e.g., they try to regain employability by becoming young again, while stressing their experience in a field). When the identity paradox they encounter cannot easily be escaped using existing resources, it seems to push them towards the development of new identities, social positions and practices within which the paradox can be re-signified. We refer to this as the possibility of a pattern shift. 


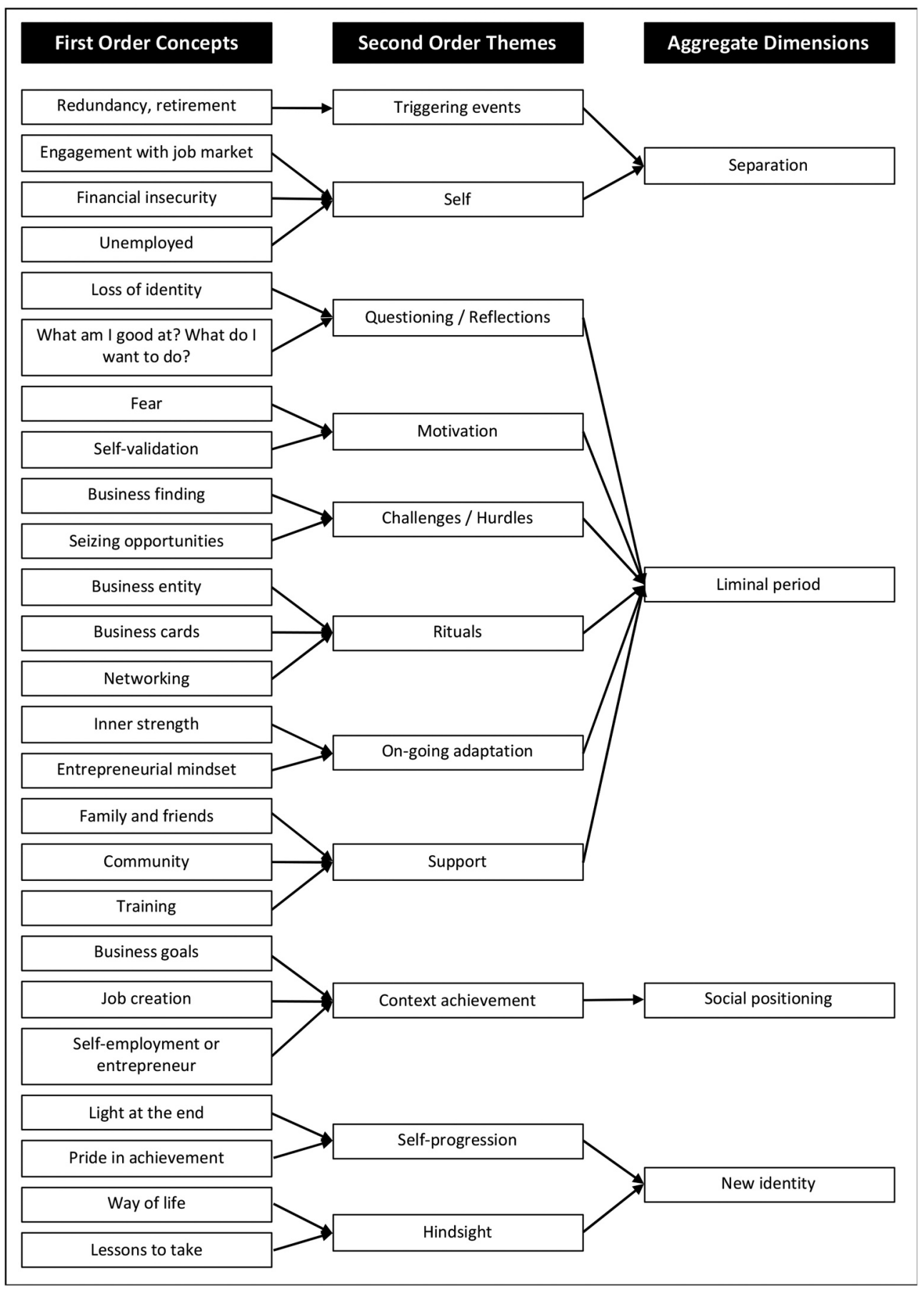

Figure 1. Thematic analysis of older entrepreneur data corpus.

Once the identity tensions in each personal liminal story were identified, we focused on making explicit the process of liminal identity work. Turning points - moments where older entrepreneurs indicated a pattern shift in the course of the process of entrepreneuring and identity positioning - in each narrative were identified. We also identified a main image of entrepreneurship in each narrative that 


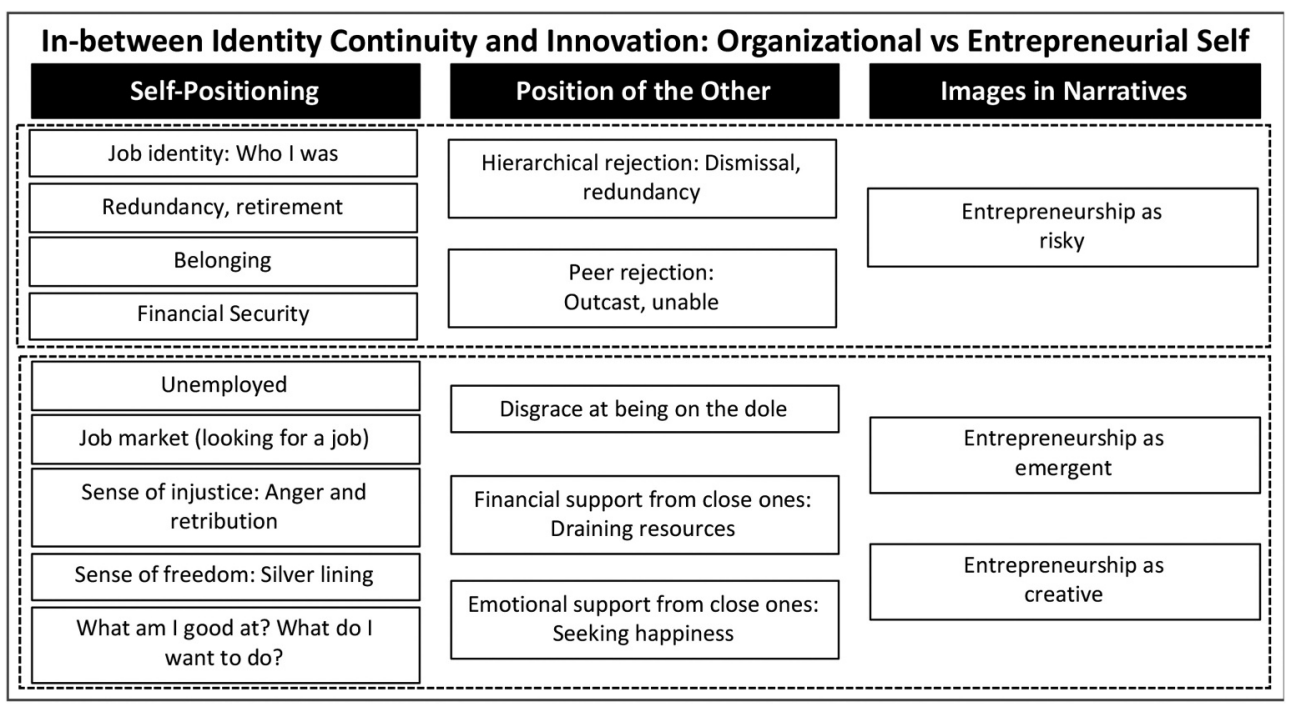

\begin{tabular}{|c|c|}
\hline \multicolumn{2}{|c|}{ Experience vs Creativity: Older vs Younger Entrepreneurs } \\
\hline Self-Positioning & Position of the Other \\
\hline Inner strength & Images in Narratives \\
\hline Being young: Having energy & $\begin{array}{r}\text { Entrepreneurship for } \\
\text { youth }\end{array}$ \\
\hline Entrepreneurial mindset & Seeking mentoring \\
\hline Identity transition & On-going adaptation \\
\hline Trusting the path & Linancial investors as approval \\
\hline Self-progression & \\
\hline
\end{tabular}

\begin{tabular}{|c|c|}
\hline \multicolumn{2}{|c|}{ Emerging Older Entrepreneurs: Moratorium vs Craft } \\
\hline Self-Positioning & Images in Narratives \\
\hline Self-validation & Position of the Other \\
\hline Pride in achievement & Recognition \\
\hline Patching the bridge to retirement & Entrepreneurship as \\
\hline Lemporal
\end{tabular}

Figure 2. Analysis of identity tensions.

provided a unifying narrative theme. This further analysis allowed us to identify the different positions that older entrepreneurs assign to themselves and others, and their effect on how they see the process of entrepreneuring. 


\section{Findings: narratives of older entrepreneuring}

Below we illustrate how older entrepreneurs articulate the process of emergent entrepreneurship through narrating their encounters with paradox, interruptions, and potential pattern shifts. The narratives also show how older entrepreneurs position themselves in their entrepreneuring narratives while engaging in identity work, and manage identity tensions, both discursively and practically, during their liminal transition process. Table 1 summarizes the key narrative identity tensions and liminal dimensions that emerged from our analysis.

\section{Confronting paradox: between identity continuity and innovation}

Most people, when facing an end to their careers, must give up a valued position, a close work relationship, team membership, or a cherished work location (Hoyer and Steyaert 2015), and such loss can generate 'a liminal state between letting go of the old and moving on to a new identity' as part of the transitional process (Conroy and O'Leary-Kelly 2014, 67). Turner $(1974,233)$ describes this process as being 'situationally and temporarily set apart' from others. The transition induces identity tensions and paradoxes, since untested projections of a future self are often not able to keep up with wellgrounded and historically defined self-images (Gabriel, Gray, and Goregaokar et al. 2010). For older entrepreneurs, age is usually a factor that triggers separation and the resulting paradox through a series of events such as redundancy, constructive dismissal, or unfulfilling (temporary) jobs.

They thought I was old but [when] I left I didn't want people to think there was a problem. So that's why I said I was retiring. I am old, you see, and no one asked questions. What I was really intending was for [a] sabbatical to see what my next step would be. Never thought that would be the end of the line [but] I fell off a cliff. I've been out of work now for 16 months, working on my own stuff. But my plan was to take a 12-month break from employment. To sort myself out ... not sure I have. (Male, age 63, currently PRIME Trainer).

In their narratives, prompted by age, the initial separation from a previous identity or social position tends to be followed by a phase of experimentation in which older entrepreneurs try out different forms of temporary attachment to other groups or identities (Ibarra and Obodaru 2016). This process entails constant self-questioning and reflection (Beech 2011), along with reacting to (or absorbing) external influences and perceptions. This betwixt-and-between transition status is inherently paradoxical. Most older entrepreneurs report spending some time still intensely involved with their old work identity, while they start to become committed to, yet are unsure about, what their new future holds. Thus, we found a tension between them maintaining coherence with a previous work identity and immersing themselves into what the new, potential entrepreneurial identity requires from them.

\footnotetext{
I was and I still am very wedded to the NHS (National Health Service, U.K.) ... [Forced to leave a job I did for many years] I felt rejected, redundant ... But, when you stop being a consultant, you can't default into thinking I am just a pair of spare hands. So, I am still a consultant, but people have to know what you stand for and they expect a maverick. So, I need to identify a business or a product or service, build a team, find the market, get everything to work and then move on, and then maybe find another one and do the same thing! So, maybe I can do that as a doctor or consultant, but might need to become something new. (Female, age 57, current job Business Consultant to NHS)
}

The paradox of being both ex-employee and future entrepreneur is also present in the position the 'other' - e.g., family, friends, employers, proximal community - is given in narratives. On the one hand, as ex-employees, older entrepreneurs feel rejected and forgotten by ex-employers who see them as old. At the same time, the 'other' is positioned as demanding them to perform, find another job, achieve clarity in purpose, and answer the question 'who are you?'. As a response, older entrepreneurs report both trying to advance their new ventures and re-engaging in traditional job search practices.

It is a very hard psychological process and you need support, almost like Alcoholics Anonymous, to acknowledge 'I'm terrified' or 'I'm worried about the bottom line and whether I'm going to be eating through the bottom line'. I am old, and this is so scary, I get panic attacks all the time. And my family and friends still expect you to perform. 


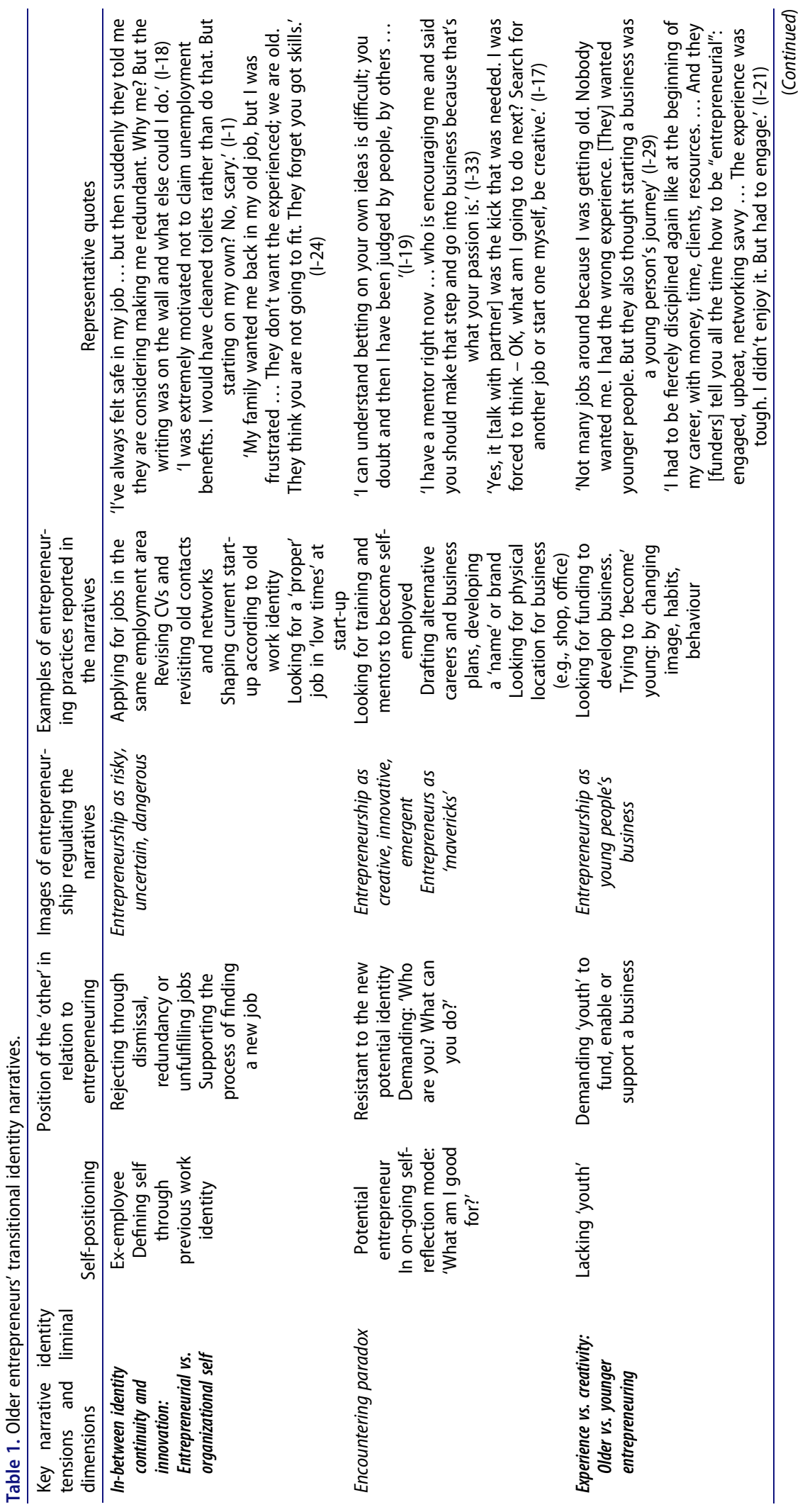




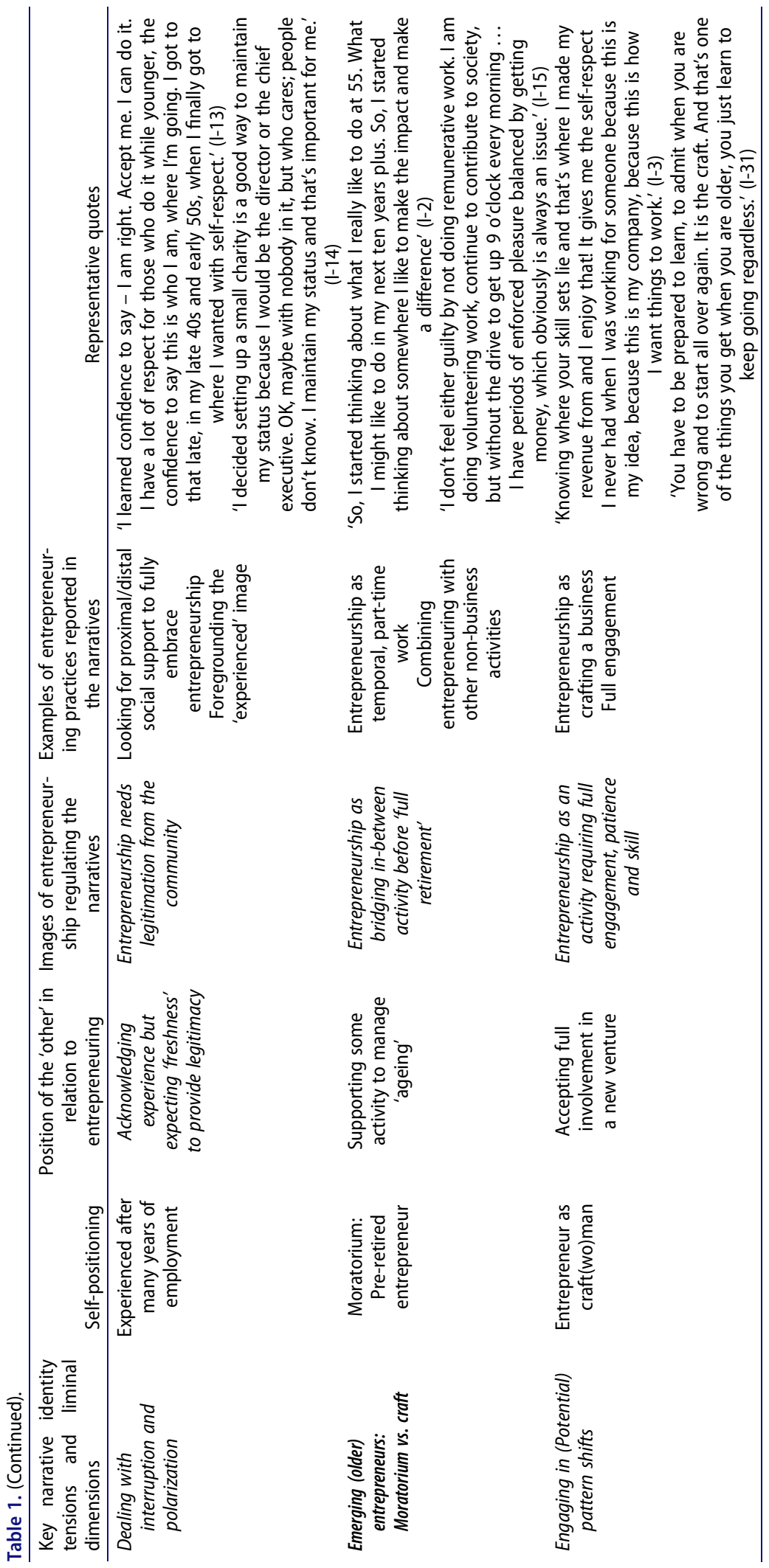


But this is something I really want because I'm qualified to do it, not because I can play the corporate game. Because, if I'm going to do that, I might as well be qualified as an accountant and get a regular pay cheque. The job that I do now is so haphazardously paid that I only do it because I like it and it is me, not because I can bring in what I call 'a corporate lifestyle'. There is no point. But it is difficult to convince family, friends. They need to trust you. You need to trust you. (Female, age 52, current job Life Coach)

The narratives reporting these identity tensions are anchored in particular images of what it is to be an entrepreneur or an employee. The entrepreneur's qualities of 'resourcefulness, nimbleness [and] subtle cunning' (Bird 1992, 207) are portrayed as opposed to the routine, disillusion, but safety (Jones and Spicer 2010) of traditional employment roles. Indeed, while interviewees describe entrepreneurs as more creative, innovative and freer than traditional employees, employment lures them back with the potential of safety, regularity and better pay (Tomlinson and Colgan 2014).

\footnotetext{
At the age of 57-years-old, I was made redundant. I am old and difficult to hire. I'm struggling to keep my head above water and, in fact, am going to have to ask my mother, who is in her eighties, to help me out financially. As a single person, I have no partner to help and no savings. I had a job that gave me an identity, and, without it, I found myself floundering. But it was something with music and people with disabilities that I wanted to do, so I'm rediscovering the passion and the excitement of doing something new, entrepreneurial, with social value. (Male, age 58, current job Music Teacher)
}

In the above stories, the tension is between going back to their employment identity and trying something new. Age is both a trigger for the shift and an obstacle to go back to previous identities and professional positions. The concept of liminality is applicable here if we attend to what happens at the point of passage between these two identities and social positions. The narratives above outline what Turner (1977c, 37) calls the 'betwixt-and-between' nature of liminality and help us to grasp what older entrepreneurs experience when becoming stuck in a liminal situation. In our case, when the two identities and social positions of (ex-)employee and potential entrepreneur overlap, they interfere with one another and older entrepreneurs find themselves caught up in the noise between their different demands.

\section{Interruption and polarization: between the experienced and the creative self}

The competing demands of the overlapping identities and social positions outlined above present older entrepreneurs with the equivalent of two mutually contradictory directives. Entering into a liminal transition, they move from a clear logic of being either an employee or an entrepreneur to a paradox logic that includes being both. At the liminal stage, however, the tension between those two identities becomes experienced not so much as both/and but as neither/nor in the sense that older entrepreneurs feel neither employees nor (yet) entrepreneurs. This identity tension sets the main scene in the polarization narratives, along with generating frustration and attempts to find a quick escape from the confusion of this liminal phase so that they can involve themselves again with a workable and clear identity, with recognizable limits. Engaging in some entrepreneurship activity, such as looking for a loan to start the business or networking to extend their social capital, brings the paradox and consequent frustration to the surface.

\footnotetext{
There are quite a lot of loans available when I go online ... free interest loans and dah dah dah ... but HOW AM I GOING TO PAY THAT BACK? I do not have a job. I'm not employed. I cannot bring collateral. And I'm 'too old' for them. So, I might not have the time to pay that loan back. And a lot of these networks also assume that you can drive quite long distances, and all assume you have computers and so on. You really have to fight the feeling of being not able, lacking money, too old, lacking time, and end up thinking that maybe it is better to just go for 'normal' retirement. Become retired. (Male, age 57, current job Freelance Photographer)
}

Within these narratives, older entrepreneurs position themselves as initially paralysed. The paradox of having to be both an ex-employee who needs to use their career experience, networks, and social capital (Davidsson and Honig 2003), while at the same time reinventing oneself, being creative and young if they are to succeed in becoming entrepreneurial (Rigolizzo and Amabile 2015), paralyses 
them to the extent that it confuses and interferes with the flows of experience and activity ordinarily channelled by, and into, their previous clear social positions and identities.

[F]rankly, so far, it has been difficult for me to keep body and soul together doing self-employed work. The difficulty I've got at the moment is that I'm still - I suppose, really, the spanner was I wasn't expecting so many people to turn around to me, when I left, and say, 'We've got a job for you. Come and be employed by us'. Every time you go into a patch where there isn't much work, you think to yourself, 'Wow, was that my last job? When will I start again? Can I do this at my age?' (Female, age 59, current job Business Consultant)

The 'other' is also portrayed as demanding youth and using age as an exclusionary marker. The paradox of having to be both experienced ex-employees and fresh to become entrepreneurs results in a polarization of their behaviour as they seek to escape their predicament of indeterminacy by forcing a solution that conforms to one of the identities and social positions they are caught between.

People tell you that as you get older you do get tired more quickly. But being able to [do] my own thing can really re-energise me. It is true that when you are young, you are much more of a risk taker. Then, you become risk adverse, [aware of] everything negative, and are scared of being a failure. But, as an entrepreneur, you have to become a risk taker. Whether by the time you are 65 you are more cautious and wiser, but you still need to be going for [development]. The thing is, there's a risk in whatever you do. There are also risks in doing nothing. So, I rather go for as much development and risk as I can stomach. At least I tried. (Male, age 70, current job Commercial Mentor)

The main cultural image of entrepreneurship guiding this narrative, and against which older entrepreneurs fight to adjust and find legitimacy, is one of youth. The entrepreneurship as a youthful endeavour narrative (Ainsworth and Hardy 2008) questions if the old can be creative, innovative and playful. Thus, older entrepreneurs struggle to overcome a narrative foreclosure implying that, by virtue of being older, the story of their working lives is essentially over (Freeman 2010). A common response is trying to become younger, following 'successful ageing' (Andrews 2009) narratives.

The thing about when you get older, people's excuses for not giving you the job or the funding become more annoying. You know it's a numbers game and you just think they want a pretty girl on the left or the young ambitious guy on the right. And the danger is that you try to become 'younger' to convince the bank manager to give you a loan for the business. I found myself dying my hair, thinking of losing weight, dressing younger when going to those interviews and that is a losing game, it just didn't happen. So, after a particularly painfully unsuccessful one, I decided to rethink what I was good at and started putting my age and my experience forward, not hiding it. (Male, age 60, current job Head of Charity)

As Turner (1977b) indicated, the liminal phase is designed to maximize the propensity for participants to become affected, so that old identities and social positions may be relinquished and new ones acquired, and so that personal dispositions may be aligned with the requirements of the individual's new role. The stories above show how, in the actual, on-going practice of entrepreneuring, personal identities and entrepreneuring activities are thoroughly intertwined and inseparable. However, the narratives also show how significant changes within and between social positions and activities can lead to entrepreneurial identities and activities being de-coupled.

With regard to identity work, in a liminal situation, the basic questions of 'who are you?' (the point of view of the other) and 'who am I?', which usually form an inseparable unity, can become distinctly problematic and out of joint. Furthermore, the identity work tensions expressed in this polarization narrative indicate that starting a shift in subjective position ('who am I?') is not enough to make the identity transition real for older entrepreneurs; the shift in position needs to be intersubjectively recognized. Thus, older entrepreneurs who transition successfully to a new identity and social position express the need to be recognized as legitimate entrepreneurs by other key social actors, presupposing the question 'who are you?'. The first question ('who am I?') challenges older entrepreneurs to make the identity transition personally real, while the second ('who are you?') challenges them to make it socially real. 


\section{Pattern shift: older entrepreneuring as moratorium or art form}

Research indicates that entrepreneurial identities develop through a variety of relational processes that shape emergent entrepreneurs' identities and practices (Anderson, Drakopoulou Dodd, and Jack et al. 2012). Older entrepreneurs develop new patterns of action by understanding and integrating what they encounter in their personal transitions into something meaningful and actionable. However, these transitions can sometimes become troubled.

Future? From a perspective of future, retirement is not retirement, not an option, never going to be zero work. I'll be working less. So, if today I'm working eight hours a day, maybe when I'm 70 I'll be working four or eight hours in a week. But l'll need to be working in whatever, enough to be able to feed myself. 60 is not very old. Now that people have to work 'til 67, if you're out of work at 50, say, that's 16 years on the job scene, okay. Forever. That's an awful long time on very low money. (Male, age 60, current job Copy Writer)

The identity tension in these narratives is between starting a business as a slower way to retire and really developing something new and worthwhile. Older entrepreneurs use the images of pre-retired or craft(wo)man to position themselves in these narratives. The term 'moratorium' (Gabriel, Gray, and Goregaokar et al. 2010, 1703) describes a kind of socially acceptable limbo-land of experimentation, where self-employment, early retirement, short-term ad hoc work, and returning to education and training feature as possible options.

My pension is rubbish. I cannot retire at 55. My husband is already retired. If I were to do something until I am 70 , I really need to do something that could make a difference to the world and give me some remuneration at the end of it. Now, it might need to be retraining or any short-term work or becoming a volunteer. So, this is a chance to think about who I am, what I enjoy, and do it. Good thing I don't have dependants right now. If not, it would be difficult. (Female, age 55, current job Carer)

An alternative positioning for the self emerges when older entrepreneurs imagine a different ending beyond retirement. Becoming older is then used as the situation that allows them to consider their lives in a new light and keep possibilities open against particular grand entrepreneuring narratives. Becoming older enables them to reconfigure their lives through experiences with families, friends and the wider community.

I was 74 at the time — a long time ago - I was born in 1933. I was developing a game for blind people and the partially sighted. I called it Dunes. I got an award at GWIIN for that. I'm still working on that. It's been through a lot of prototypes, development, but I think I've got the sort of thing that the market wants. But I need cash to develop the prototype, so I've just taken equity release out on my flat in [London]. Yes, I've had to consider life expectancy, actuarial tables, so I'm aware that I've got a time limit, not a lot left. [But,] it makes me feel good. I'm a bit of an artist and the gaming community doesn't care about age. (Female, age 83, current job Games Designer)

When the paradox of being old but having to become fresh to succeed entrepreneurially cannot easily be escaped using existing resources, it pushes those involved towards the invention of new identities and social positions, presenting the possibility of a pattern shift. Older entrepreneurs who can linger in this liminal space/time enjoy a distinctive and complex experience that forms the basis of a new identity and social position.

I fear to have 30 or 40 years sitting at home reading books ... doing nothing. My brain shrivels at that thought. So, to keep going, the self-validation is most important because I couldn't conceive not doing anything. So, it is a question of how best to use my skills and energy for as long as I can. So, you start adjusting. I now have a powerful looking business card, a title, I dress smartly, and I do what they now are calling 'fake it 'til you make it'. Old or not, I'm on it, enjoying the challenge and learning. (Female, age 54, current job Film Producer)

Liminality is the condition of being caught between two mutually exclusive identity alternatives (being older and being entrepreneurial) and potentially becoming paralysed by the contradiction between them. The potential pattern shift our analysis outlines involves the re-signification of this contradiction in the context of a new identity and social position.

In my industry, a woman is really ancient at 55 and so not a great time to start a business. Looking around everyone's 20, 25 years younger than me, sitting there in coffee shops with their laptops. I thought, 'Oh, maybe 
I'm a bit too old'. But then, I don't think I am. I know all the clients and I know them very well and have done for some time; and, second, I am me, you know? I can do, can sell, can create. And that does not depend on being a number. It is a skill, a craft. (Female, age 60, current job IT Support Engineer)

It is here that we can talk about a sense of identity re-aggregation, which follows a transition where one does not return to normal but is gradually able to construct a new identity (Ibarra and Obodaru 2016) and move to a new understanding of self and community (Turner 1977b). Not all older entrepreneurs reach re-aggregation, but some are ready to do so; however, for this change to be real, it requires social recognition. It also requires that the change is not just an externally imposed categorization.

There are SO many variables and sometimes it makes me question why I am doing this and whether it is worth it. It eventually will be. You have to remain positive. You have to believe in what you're doing so much that a negative here and there doesn't affect that belief. And you have to be very patient, craft it. I know that because I'm old. It's not going to work if you're impatient. Being old has its advantages. You know how to let everyone else do their own thing. I'm beyond competition. Working for me is a pleasure. Your belief has to be that strong. (Male, age 70, current job Commercial Mentor)

What the narratives outlined above bring clearly forward is the tension between potential and actual identities for older entrepreneurs. Any liminal transition will require older entrepreneurs to make investments both at the psychological and the social activity levels, and to manage the interruptions associated with such transitions, that disturb both 'the life of society and the individual' (van Gennep $1960,13)$. Because social positions are tightly coupled with identities, any transition in social position requires a corresponding shift in identity. This requires older entrepreneurs to face both past and future identities and social positions at the same time. In facing the past, older entrepreneurs must extricate themselves from the understandings and activities of a now redundant identity and social position. Facing the future, on the other hand, older entrepreneurs rarely slot frictionlessly into a new identity; they must learn to inhabit it, which means familiarizing themselves with what the new habitat affords, and creatively modifying it according to desires and capabilities.

\section{Discussion}

Entrepreneurship has been gaining increased attention as a feasible occupational strategy for older individuals, emerging either as a lifestyle option or as an inevitability due to insufficient income and lack of opportunities in the formal labour market in later life (Kautonen, Kibler, and Minniti et al. 2017). However, there is still insufficient research addressing older entrepreneurship beyond the motivations to become an entrepreneur. Our research takes a wider view of the process of becoming an entrepreneur in later life by looking at the transition older entrepreneurs experience from a liminal identity perspective.

The late life transition into entrepreneurship is ultimately a liminal, transformative process of creating possible futures and states of being, while existing as would-be entrepreneurs (Anderson 2005). In starting their entrepreneurial journey, older entrepreneurs find themselves temporarily undefined as they move from employment or early retirement towards a potential entrepreneurial identity. In between lies a liminal phase, where they accept having moved beyond their earlier roles but have not yet acquired the new entrepreneurial one. In this liminal phase, they are invisible, with no recognized social or institutional position: they are in-between and betwixt (Turner 1977b). This resonates with research that understands entrepreneurship itself as a transition, where the 'entre' can refer to an 'in between' border zone (Steyaert 2005, 7).

Our analysis has further uncovered the particular paradoxical characteristics of a liminal identity transition. In the liminal phase, older entrepreneurs confront identity paradoxes that lead to interruptions in their sense of self and their activities. Being both ex-employee and potential entrepreneur, experienced and anew, generates a tension between attempting both identity continuity and innovation, and shapes their understanding of entrepreneurship as both risky and desirable. This 
identity paradox challenges the usefulness of previous experiences and activity patterns, hence older entrepreneurs find themselves simultaneously searching for a job similar to the one left behind while trying to set up a new business and recreate themselves anew.

Our results resonate with recent calls in organizational paradox research to go beyond an exclusive focus on duality and embrace the transition and complexities involved in paradoxical situations (Jarzabkowski 2018). Accordingly, our results reflect the continuous identity work required to balance potentially opposing, but mutually dependent, identities, such as 'older' and 'entrepreneur', to move towards identity shifts rather than stressing polarized identity dualities (Farjoun 2010). Using a paradox lens to explore older entrepreneuring not only allows us to look at contradictory, but interdependent, identity aspects, but also enables us to move beyond dilemmas, trade-offs, and conflicts, which are usually solved by splitting and choosing between conflicting identities (Fairhurst et al. 2016). In fact, no choice needs to be made amongst contradictory aspects, since 'paying attention to one alternative while neglecting its opposite can easily lead to a deficiency' (Tse 2013, 694), eventually disrupting identity development.

Once rendered salient, paradoxical identity tensions stimulate either positive or negative responses (e.g., Poole and Van de Ven 1989) in the form of diverse narrative positions and entrepreneuring practices. Older entrepreneurs' attempts to resolve the identity paradox they confront include strategies that try to overcome or accommodate tensions (Lewis 2000), like embracing both 'older' and 'entrepreneur' identities as distinct, yet mutually enabling, and trying to avoid practices that lead towards one of the poles in the paradox, such as trying to become younger at all costs, to generate legitimacy. As the identity work tensions expressed by older entrepreneurs indicate, starting a shift in subjective position ('who am I?') is not enough to make the identity transition real; the shift in identities and social positions also needs to be intersubjectively recognized. Such identity work efforts aid self-directed action by helping older entrepreneurs to reflect and act upon their own identity tensions (Zanoni and Janssens 2007), leading to a constant examination of the self and 'others', particularly in relation to the entrepreneuring journey. As Anderson, Drakopoulou Dodd, and Jack et al. (2012) state, entrepreneuring is very much about the process of becoming, and becoming is always a co-production between the entrepreneur, the generalized other, and their socio-cultural-historical context.

Lying outside the mainstream, the liminal state allows for liberation from routine social structures, norms of behaviour, and other expectations (Tempest and Starkey 2004). This indicates that liminal periods can also be periods of increased creativity and innovation, as those involved take advantage of the additional freedoms and lack of constraints. When the paradox of being old but having to become fresh cannot easily be escaped using existing resources, it can push those involved towards acceptance and, ultimately, the invention of new identities and social positions. Those older entrepreneurs who manage to accept the identity interruptions and polarization their transition brings move away from an initial sense of isolation and are able to bring a creative understanding to entrepreneuring processes. Liminality, despite potential negative consequences, may lead to a sense of autonomy and personal freedom, as older entrepreneurs start to transcend institutional and social constraints. Such position can enhance opportunities for creative thinking as, unbound by structural procedures (Garsten 1999), individuals challenge existing boundaries (Sturdy, Schwarz, and Spicer et al. 2006), potentially fostering deviation and originality (Turner 1977b). Thus, it is in conditions of liminality where we find that alternative and creative understandings tip the balance, allowing older entrepreneurs to develop new identities as entrepreneurs.

Our analysis also illustrates how, like other identity categories, age works as a master signifier to shape ways of thinking, being and doing, establishing what we can see as reality and truth, and both creating and constraining meanings related to age. We have seen how some older entrepreneurs talk about actively keeping young, trying to fulfil the demands of 'successful ageing' (Andrews 2009), imitating the 'young guns' (Down and Reveley 2004) with the risk of alienation, or fighting a narrative foreclosure where the story of their working lives is essentially over (Freeman 2010). However, we have also seen how new, creative understandings can be developed among older entrepreneurs, 
where being older is generative such that there is learning, identity transformation, renewed sensemaking, and new ways of doing.

Our results support studies that found entrepreneurial identity development intersecting with other identity markers, such as ethnicity and gender (Cohen and Musson 2000). So far, however, there is little research of how entrepreneurial identity signifiers intersect with age-based identity markers, particularly old age. The relationship between older entrepreneurs and entrepreneurial perceptions is important for a number of reasons: older employees bear the brunt of enterprise-led reforms in that they are often targeted for redundancy (De Bruin and Firkin 2001); success at ageing is judged in relation to the extent to which the processes of ageing can be minimized (e.g., Trethewey 2001); and, old age is different to youth insofar as the discussion is about eliminating old age, not youth.

As entrepreneurs need to be able to 'tell themselves' (Rae and Carswell 2000), it is important to understand how older entrepreneur narratives are constructed. We have seen how older entrepreneurs take and assign identity positions to themselves and others (van Langenhove and Harré 1999) when describing their transition in entrepreneuring narratives and how those positions relate to particular images, narratives, and practices of entrepreneurship through which they do and redo entrepreneuring (Steyaert 2007). For instance, entrepreneuring is seen variously as risky, creative, young persons' work, or art form throughout the different narratives where older entrepreneurs portray themselves also in a diversity of positions from ex-employees to crafts(wo)men. Thus, as older entrepreneurs confront identity paradoxes and their identity narrative position changes, their perception of entrepreneuring, along with the way they act, changes too.

\section{Conclusions}

We have illustrated, empirically, how older entrepreneurs experience the transition into entrepreneurship from a liminal identity work perspective. We see the contributions of our research as threefold.

First, in uncovering the liminality inherent in their transitions, our research captures the inbetween identity struggles older entrepreneurs experience in their journey towards entrepreneurship. Older entrepreneurship research focuses on the motivations to start the entrepreneurial journey or the (successful) outputs of that journey, but rarely explores in-between experiences. The entrepreneuring efforts that are not explicitly or directly involved in the production of those (novel and useful) outputs are usually dismissed as not entrepreneurial or interesting enough. However, focusing only on motivations to start the journey or on the end result of (successful) outputs is at the expense of recognizing the psychological and relational processes needed in the process to become entrepreneurs. Those in-between identity shifts we have observed in our research could be just the one necessary step towards a subsequent action that will eventually achieve the novel entrepreneurial output, or simply change the status quo. In making liminal entrepreneuring explicit, we are able to look behind what people do, and the miscellany of identifications these doings produce, to focus on the creative good that generates persons in relationships (Lombardo and Kvålshaugen 2014). This creative capacity of entrepreneuring is a process in which older entrepreneurs not only attempt to develop new entrepreneuring ventures but, by engaging socially, recreate themselves and their context anew.

Second, we show how older entrepreneurship is becoming one of the paradoxical identity tensions typical of current work conditions. While the paradoxical nature of these tensions has long been identified, the implications of living that paradox and trying to overcome it in generative ways have rarely been addressed. A paradox lens allows for a more holistic, fluid, both/and framing of identity tensions among older entrepreneurs. Through identity work, older entrepreneurs are able to position 'older' and 'entrepreneur' identities as two sides of the same coin, rather than as polarized contradictions. Such framing can reduce anxiety, enabling acceptance and appreciation of tensions, 
with the resulting mindset helping older entrepreneurs cope with the ambiguity inherent in entrepreneurial transitions. Our research opens new research questions in this respect.

Third, our research has clear implications for policy making. With changes to pension provision afoot in the U.K., our research provides a timely example where older entrepreneurship could play a crucial role in addressing the difficulties associated with ageing populations. For instance, in recent years, older entrepreneurs have become a focus for employment research and policies in many European countries, with employment policies promoting early retirement losing legitimacy and being replaced by measures that encourage older workers to remain in the labour force for longer (Foden and Jepsen 2002). Debates have centred around two related concepts: extending working lives, through keeping people in employment up until or beyond state retirement/pension ages; and reversing the 'one-way street' (Organisation for Economic Co-operation and Development 2006, 10) of early exit to get economically inactive older people back into work. But most people in their 50s are not ready to overhaul their social and financial positions, as well as reinvent themselves, to become entrepreneurial, so we need further research to have an understanding of employment and entrepreneuring that accounts for developments after age 50.

Scholars and policy makers increasingly emphasize that supporting older entrepreneurs can be a good strategy to tackle the socio-economic challenges emerging from an ageing population (Kautonen, Tornikoski, and Kibler et al. 2011). However, as our research shows, older entrepreneurs encounter discrimination and find it difficult to fit within narratives that frame entrepreneurship as an activity for younger individuals. Ageist expectations emerge not only from within institutional and societal discourses (Mallett and Wapshott 2015), but also from social reference groups (family, friends and clients), which can affect older entrepreneurs' efforts to develop themselves and their businesses. Further research in these areas would be necessary to understand how to support older entrepreneurship better. This is of particular importance in countries where government has recently decided to increase the state pensionable age and where, in many cases, private pensions fail to deliver adequate returns for a comfortable retirement (Wainwright and Kibler 2013). As such, there is an increasing need for further research to understand better how older individuals can engage in the labour market for longer, and how we can help them to develop their small businesses further.

\section{Disclosure statement}

No potential conflict of interest was reported by the authors.

\section{References}

Ainsworth, S., and C. Hardy. 2008. "The Enterprising Self: An Unsuitable Job for an Older Worker." Organization 15 (3): 389-405. doi:10.1177/1350508408088536.

Alvesson, M. 2010. "Self-doubters, Strugglers, Storytellers and Others: Images of Self-identities in Organizational Studies." Human Relations 63 (2): 193-217. doi:10.1177/0018726709350372.

Anderson, A. R. 2005. "Enacted Metaphor: The Theatricality of the Entrepreneurial Process." International Small Business Journal 23 (6): 587-603. doi:10.1177/0266242605057654.

Anderson, A. R., S. Drakopoulou Dodd, S. L. Jack. 2012. "Entrepreneurship as Connecting: Some Implications for Theorising and Practice." Management Decision 50 (5): 958-971. DOI:10.1108/00251741211227708.

Andrews, M. 2009. "The Narrative Complexity of Successful Ageing." International Journal of Sociology and Social Policy 29 (1-2): 73-83. doi:10.1108/01443330910934736.

Beech, N. 2011. "Liminality and the Practices of Identity Reconstruction." Human Relations 64 (2): 285-302. doi:10.1177/ 0018726710371235.

Beech, N., H. Burns, L. de Caestecker, R. Maclntosh, D. MacLean. 2004. “Paradox as Invitation to Act in Problematic Change Situations." Human Relations 57 (10): 1313-1332. DOI:10.1177/0018726704048357.

Berger, T. L., and T. Luckmann. 1966. The Social Construction of Reality: A Treatise in the Sociology of Knowledge. Garden City, NY: Doubleday.

Bird, B. J. 1992. “The Roman God Mercury: An Entrepreneurial Archetype." Journal of Management Inquiry 1 (3): $205-212$. doi:10.1177/105649269213004. 
Biron, D., and É. St. Jean. 2019. "A Scoping Study of Entrepreneurship among Seniors: Overview of the Literature and Avenues for Future Research." In Handbook of Research on Elderly Entrepreneurship, edited by A. Maâlaoui, 17-41. Cham: Springer.

Boje, D. M., and R. Smith. 2010. "Re-storying and Visualizing the Changing Entrepreneurial Identities of Bill Gates and Richard Branson." Culture \& Organization 16 (4): 307-331. doi:10.1080/14759551003769250.

Brooker, E., and M. Joppe. 2013. "Trends in Camping and Outdoor Hospitality: An International Review." Journal of Outdoor Recreation and Tourism 3/4: 1-6. doi:10.1016/j.jort.2013.04.005.

Brown, A. D. 2015. "Identities and Identity Work in Organizations." International Journal of Management Reviews 17 (1): 20-40. doi:10.1111/ijmr.12035.

Cialdini, R. B., M. R. Trost, J. T. Newsom. 1995. "Preference for Consistency: The Development of a Valid Measure and the Discovery of Surprising Behavioral Implications." Journal of Personality and Social Psychology 69 (2): 318-328. DOI:10.1037/0022-3514.69.2.318.

Cohen, L., and G. Musson. 2000. "Entrepreneurial Identities: Reflections from Two Case Studies." Organization 7 (1): 31-48. doi:10.1177/135050840071003.

Conroy, S. A., and A. M. O'Leary-Kelly. 2014. "Letting Go and Moving On: Work-related Identity Loss and Recovery." Academy of Management Review 39 (1): 67-87. doi:10.5465/amr.2011.0396.

Czarniawska, B., and C. Mazza. 2003. "Consulting as Liminal Space." Human Relations 56 (3): 267-290. doi:10.1177/ 0018726703056003612.

Daskalaki, M., and M. Simosi. 2018. "Unemployment as a Liminoid Phenomenon: Identity Trajectories in Times of Crisis." Human Relations 71 (9): 1153-1178. doi:10.1177/0018726717737824.

Davidsson, P., and B. Honig. 2003. "The Role of Social and Human Capital among Nascent Entrepreneurs." Journal of Business Venturing 18 (3): 301-331. doi:10.1016/S0883-9026(02)00097-6.

Davies, B., and R. Harré. 1990. "Positioning: The Discursive Production of Selves." Journal for the Theory of Social Behaviour 20 (1): 43-63. doi:10.1111/j.1468-5914.1990.tb00174.x.

De Bruin, A., and P. Firkin. 2001. Self-Employment of the Older Worker. Auckland: Labour Market Dynamics Research Programme, Massey University.

De Clercq, D., and M. Voronov. 2009. "Toward a Practice Perspective of Entrepreneurship: Entrepreneurial Legitimacy as Habitus." International Small Business Journal 27 (4): 395-419. doi:10.1177/0266242609334971.

Down, S., and J. Reveley. 2004. "Generational Encounters and the Social Formation of Entrepreneurial Identity: 'Young Guns' and 'Old Farts'." Organization 11 (2): 233-250. doi:10.1177/1350508404030381.

Eisenhardt, K. M., and J. A. Martin. 2000. "Dynamic Capabilities: What Are They?" Strategic Management Journal 21 (10-11): 1105-1121. doi:10.1002/1097-0266(200010/11)21:10/11<1105::AID-SMJ133>3.0.CO;2-E.

Fairhurst, G. T., W. K. Smith, S. G. Banghart, M. W. Lewis, L. L. Putnam, S. Raisch, J. Schad. 2016. "Diverging and Converging: Integrative Insights on a Paradox Meta-perspective." The Academy of Management Annals 10: 173-182. doi:10.5465/19416520.2016.1162423.

Farjoun, M. 2010. "Beyond Dualism: Stability and Change as a Duality." Academy of Management Review 35 (2): $202-225$.

Fine, G. A. 1996. "Justifying Work: Occupational Rhetorics as Resources in Restaurant Kitchens." Administrative Science Quarterly 41 (1): 90-115. doi:10.2307/2393987.

Foden, D., and M. Jepsen. 2002. "Active Strategies for Older Workers in the European Union: A Comparative Analysis of Recent Experiences." In Active Strategies for Older Workers, edited by M. Jepson, D. Foden, and M. Hutsebaut, 437-460. Brussels: European Trade Union Institute.

Freeman, M. 2010. "Narrative Foreclosure in Later Life: Possibilities and Limits." In Storying Later Life: Issues, Investigations, and Interventions in Narrative Gerontology, edited by G. Kenyon, E. Bohlmeijer, and W. L. Randall, 3-19. New York, NY: Oxford University Press.

Gabriel, Y., D. E. Gray, H. Goregaokar. 2010. "Temporary Derailment or the End of the Line? Managers Coping with Unemployment at 50." Organization Studies 31 (12): 1687-1712. DOI:10.1177/0170840610387237.

García-Lorenzo, L., P. Donnelly, L. Sell-Trujillo and M J. Imas. 2018. "Liminal Entrepreneuring: The Creative Practices of Nascent Necessity Entrepreneurs." Organization Studies 39 (2-3): 375-395.

Garsten, C. 1999. "Betwixt and Between: Temporary Employees as Liminal Subjects in Flexible Organizations." Organization Studies 20 (4): 601-617. doi:10.1177/0170840699204004.

Gerontological Society of America. 2018. Playing the Hand You're Dealt: Optimal Aging in a Diverse World. Washington, DC: Gerontological Society of America.

Giddens, A. 1991. Modernity and Self-identity: Self and Society in the Late Modern Age. Cambridge: Polity Press.

Gioia, D. A., and J. B. Thomas. 1996. "Identity, Image and Issue Interpretation: Sensemaking during Strategic Change in Academia." Administrative Science Quarterly 41 (3): 370-403. doi:10.2307/2393936.

Gioia, D. A., K. G. Corley, A. L. Hamilton. 2013. "Seeking Qualitative Rigor in Inductive Research: Notes on the Gioia Methodology." Organizational Research Methods 16 (1): 15-31. DOI:10.1177/1094428112452151.

Hamilton, E. 2014. "Entrepreneurial Narrative Identity and Gender: A Double Epistemological Shift." Journal of Small Business Management 52 (4): 703-712.

Harré, R., F. M. Moghaddam, T. P. Cairnie, D. Rothbart, S. R. Sabat. 2009. "Recent Advances in Positioning Theory." Theory \& Psychology 19 (1): 5-31. DOI:10.1177/0959354308101417. 
Hart, M., M. Anyadike-Danes, and R. Blackburn. 2004. Spatial Differences in Entrepreneurship: A Comparison of Prime Age and Third Age Cohorts. Belfast: Economic Research Institute of Northern Ireland.

Hatfield, I. 2015. Self-employment in Europe. London: Institute for Public Policy Research.

Henfridsson, O., and Y. J. Yoo. 2014. "The Liminality of Trajectory Shifts in Institutional Entrepreneurship." Organization Science 25 (3): 932-950. doi:10.1287/orsc.2013.0883.

Henley, A. 2007. "Entrepreneurial Aspiration and Transition into Self-employment: Evidence from British Longitudinal Data." Entrepreneurship \& Regional Development 19 (3): 253-280. doi:10.1080/08985620701223080.

Hoyer, P., and C. Steyaert. 2015. "Narrative Identity Construction in Times of Career Change: Taking Note of Unconscious Desires." Human Relations 68 (12): 1837-1863. doi:10.1177/0018726715570383.

Hytti, U., H. Ulla, R. Blackburn, and S. Tegtmeier, eds. 2018. The Dynamics of Entrepreneurial Contexts. Cheltenham: Edward Elgar.

Ibarra, H., and O. Obodaru. 2016. "Betwixt and between Identities: Liminal Experience in Contemporary Careers." Research in Organizational Behavior 36: 47-64. doi:10.1016/j.riob.2016.11.003.

Jarzabkowski, P. 2018. "Studying Paradox as Process and Practice: Identifying and following Moments of Salience and Latency." In Dualities, Dialectics, and Paradoxes in Organizational Life, edited by Farjoun, Moshe, Wendy Smith, Anne Langley, and Haridimous Tsoukas ., 175-194. Oxford: Oxford University Press.

Jones, C., and A. Spicer. 2010. Unmasking the Entrepreneur. Cheltenham: Edward Elgar.

Kautonen, T. 2008a. "Understanding the Older Entrepreneur: Comparing Third Age and Prime Age Entrepreneurs in Finland." International Journal of Business Science and Applied Management 3 (3): 3-13.

Kautonen, T., E. Kibler, M. Minniti. 2017. "Late-Career Entrepreneurship, Income and Quality of Life." Journal of Business Venturing 32 (3): 318-333. DOI:10.1016/j.jbusvent.2017.02.005.

Kautonen, T., E. T. Tornikoski, E. Kibler. 2011. "Entrepreneurial Intentions in the Third Age: The Impact of Perceived Age Norms." Small Business Economics 37 (2): 219-234. DOI:10.1007/s11187-009-9238-y.

Kautonen, T., S. Down, M. Minniti. 2014. "Ageing and Entrepreneurial Preferences." Small Business Economics 42 (3): 579-594. DOI:10.1007/s11187-013-9489-5.

Kautonen, Teemu, Simon Down and Lauirie South 2008b. "Enterprise Support for Older Entrepreneurs: The Case of PRIME in the U.K." International Journal of Entrepreneurial Behaviour and Research 14 (2): 85-101.

Kibler, E., T. Wainwright, T. Kautonen, R. Blackburn. 2015. “Can Social Exclusion Against 'Older Entrepreneurs' Be Managed?" Journal of Small Business Management 53 (S1): 193-208. DOI:10.1111/jsbm.12194.

Langley, P. 2006. "The Making of Investor Subjects in Anglo-American Pensions." Environment and Planning. D, Society \& Space 24 (6): 919-934. doi:10.1068/d405t.

Leitch, C. M., and R. T. Harrison. 2016. "Identity, Identity Formation and Identity Work in Entrepreneurship: Conceptual Developments and Empirical Applications." Entrepreneurship \& Regional Development 28 (3-4): 177-190. doi:10.1080/ 08985626.2016.1155740.

Lévesque, M., and M. Minniti. 2006. "The Effect of Aging on Entrepreneurial Behavior." Journal of Business Venturing 21 (2): 177-194. doi:10.1016/j.jbusvent.2005.04.003.

Lévesque, M., and M. Minniti. 2011. "Age Matters: How Demographics Influence Aggregate Entrepreneurship." Strategic Entrepreneurship Journal 5 (3): 269-284. doi:10.1002/sej.117.

Lewis, M. W. 2000. "Exploring Paradox: Toward a More Comprehensive Guide." Academy of Management Review 25 (4): 760-776. doi:10.5465/amr.2000.3707712.

Lewis, M. W., and W. K. Smith. 2014. "Paradox as a Metatheoretical Perspective: Sharpening the Focus and Widening the Scope." The Journal of Behavioural Science 50 (2): 127-149.

Lombardo, S., and R. Kvålshaugen. 2014. "Constraint-Shattering Practices and Creative Action in Organizations." Organization Studies 35 (4): 587-611. doi:10.1177/0170840613517597.

Lüscher, L. S., and M. W. Lewis. 2008. "Organizational Change and Managerial Sensemaking: Working through Paradox." Academy of Management Journal 51 (2): 221-240. doi:10.5465/amj.2008.31767217.

Mallett, O., and R. Wapshott. 2015. "Making Sense of Self-employment in Late Career: Understanding the Identity Work of Olderpreneurs." Work, Employment and Society 29 (2): 250-266. doi:10.1177/0950017014546666.

McAdams, D. P., and K. C. McLean. 2013. "Narrative Identity." Current Directions in Psychological Science 22 (3): $233-238$. doi:10.1177/0963721413475622.

Noble, C. H., and B. A. Walker. 1997. "Exploring the Relationships among Liminal Transitions, Symbolic Consumption, and the Extended Self." Psychology \& Marketing 14 (1): 29-47. doi:10.1002/(SICI)1520-6793(199701)14:1<29::AIDMAR3>3.0.CO;2-Q.

Office for National Statistics. 2019. Labour Market Overview. London: Office for National Statistics.

Organisation for Economic Co-operation and Development. 2006. Live Longer, Work Longer. Paris: Organisation for Economic Co-operation and Development.

P. Sandvik Pamela. 2008. Intensive Remedial Identity Work: Responses to Workplace Bullying Trauma and Stigmatization. Organization 15 (1): 97-119. doi:10.1177/1350508407084487

Parker, M. 2000. Organizational Culture and Identity: Unity and Division at Work. London: Sage.

Parker, S. C. 2009. The Economics of Entrepreneurship. Cambridge: Cambridge University Press. 
Pensions and Lifetime Savings Association. 2010. Hitting the Target: A Vision for Retirement Income Adequacy. London: Pensions and Lifetime Savings Association.

Poole, M. S., and A. H. Van de Ven. 1989. "Using Paradox to Build Management and Organization Theories." Academy of Management Review 15 (3): 562-578. doi:10.5465/amr.1989.4308389.

Rae, D., and M. Carswell. 2000. "Towards a Conceptual Understanding of Entrepreneurial Learning." The Journal of Small Business and Enterprise Development 8 (2): 150-158. doi:10.1108/EUM0000000006816.

Riach, K., and W. Loretto. 2009. "Identity Work and the 'Unemployed' Worker: Age, Disability and the Lived Experience of the Older Unemployed." Work, Employment and Society 23 (1): 102-119. doi:10.1177/0950017008099780.

Riessman, C. K. 2008. Narrative Methods for the Human Sciences. Thousand Oaks, CA: Sage.

Rigolizzo, M., and T. Amabile. 2015. "Entrepreneurial Creativity: The Role of Learning Processes and Work Environment Supports." In The Oxford Handbook of Creativity, Innovation, and Entrepreneurship, edited by C. E. Shalley, M. A. Hitt, and J. Zhou, 61-78. New York, NY: Oxford University Press.

Schad, J., M. W. Lewis, S. Raisch, W. K. Smith. 2016. "Paradox Research in Management Science: Looking Back to Move Forward." The Academy of Management Annals 10: 5-64. doi:10.5465/19416520.2016.1162422.

Singh, G., and A. DeNoble. 2003. "Early Retirees as the Next Generation of Entrepreneurs." Entrepreneurship Theory and Practice 27 (3): 207-226. doi:10.1111/1540-8520.t01-1-00001.

Smith, W. K., M. Erez, S. Jarvenpaa, M. W. Lewis, P. Tracey. 2017. “Adding Complexity to Theories of Paradox, Tensions, and Dualities of Innovation and Change." Organization Studies 38 (3-4): 303-317. DOI:10.1177/0170840617693560.

Smith, W. K., and M. W. Lewis. 2011. "Toward A Theory of Paradox: A Dynamic Equilibrium Model of Organizing." Academy of Management Review 36 (2): 381-403.

Steyaert, C. 2005. "Entrepreneurship: In between What? on the 'Frontier' as a Discourse of Entrepreneurship Research." International Journal of Entrepreneurship and Small Business 2 (1): 2-16. doi:10.1504/IJESB.2005.006066.

Steyaert, C. 2007. "Entrepreneuring' as A Conceptual Attractor? A Review of Process Theories in 20 Years of Entrepreneurship Studies." Entrepreneurship \& Regional Development 19 (6): 453-477. doi:10.1080/ 08985620701671759.

Stirzaker, R. J., and L. Galloway. 2017. "Ageing and Redundancy and the Silver Lining of Entrepreneurship." The International Journal of Entrepreneurship and Innovation 18 (2): 105-114. doi:10.1177/1465750317706441.

Sturdy, A., M. Schwarz, A. Spicer. 2006. "Guess Who's Coming to Dinner? Structures and Uses of Liminality in Strategic Management Consultancy." Human Relations 59 (7): 929-960. DOI:10.1177/0018726706067597.

Sveningsson, S., and M. Alvesson. 2003. "Managing Managerial Identities: Organizational Fragmentation, Discourse and Identity Struggle." Human Relations 56 (10): 1163-1193. doi:10.1177/00187267035610001.

Tempest, S., and K. Starkey. 2004. "The Effects of Liminality on Individual and Organizational Learning." Organization Studies 25 (4): 507-527. doi:10.1177/0170840604040674.

Tomlinson, F., and F. Colgan. 2014. "Negotiating the Self between past and Present: Narratives of Older Women Moving Towards Self-employment." Organization Studies 35 (11): 1655-1675. doi:10.1177/0170840614550734.

Toyoki, S., and A. D. Brown. 2014. "Stigma, Identity and Power: Managing Stigmatized Identities through Discourse." Human Relations 67 (6): 715-737. doi:10.1177/0018726713503024.

Trethewey, A. 2001. "Reproducing and Resisting the Master Narrative of Decline: Midlife Professional Women's Experiences of Aging." Management Communication Quarterly 15 (2): 183-226. doi:10.1177/0893318901152002.

Tse, T. 2013. "Paradox Resolution: A Means to Achieve Strategic Innovation." European Management Journal 31 (6): 682-696. doi:10.1016/j.emj.2013.05.001.

Turner, V. W. 1974. Drama, Fields and Metaphors: Symbolic Action in Human Society. Ithaca, NY: Cornell University Press.

Turner, V. W. 1977a. The Ritual Process: Structure and Anti-structure. Ithaca NY: Cornell University Press.

Turner, V. W. 1977b. "Process, System, and Symbol: A New Anthropological Synthesis." Daedalus 106 (3): 61-80.

Turner, V. W. 1977c. "Variations on a Theme of Liminality." In Secular Ritual, edited by S. F. Moore and B. Meyerhoff, 36-52. Assen, Netherlands: Van Gorcum.

van Gennep, A. 1960. The Rites of Passage. Translated by M. B. Vizedom, and G. L. Caffee. Chicago, IL: University of Chicago Press.

van Langenhove, L., and R. Harré. 1999. "Introducing Positioning Theory." In Positioning Theory: Moral Contexts of Intentional Action, edited by R. Harré and L. van Langenhove, 14-31. Oxford: Blackwell.

Wainwright, T., and E. Kibler. 2013. "Beyond Financialization: Older Entrepreneurship and Retirement Planning." Journal of Economic Geography 14 (4): 849-864. doi:10.1093/jeg/lbt023.

Weber, P., and M. Schaper. 2004. "Understanding the Grey Entrepreneur." Journal of Enterprising Culture 12 (2): $147-164$. doi:10.1142/S0218495804000087.

Wenger, E. 1998. Communities of Practice: Learning, Meaning and Identity. Cambridge: Cambridge University Press.

World Economic Forum. 2018. The Future of Jobs Report, 2018. Geneva: World Economic Forum.

Xavier, S. R. , D. Kelly, J. Kew, M. Herrington and A. Vorderwulbecke. 2013. Global Entrepreneurship Monitor 2012 Global Report. Accessed 17 March 2020. http://www.gemconsortium.org/report/48545

Zanoni, P., and J. Janssens. 2007. "Minority Employees Engaging with (Diversity) Management: An Analysis of Control, Agency, and Micro-emancipation." Journal of Management Studies 44 (8): 1371-1397. 